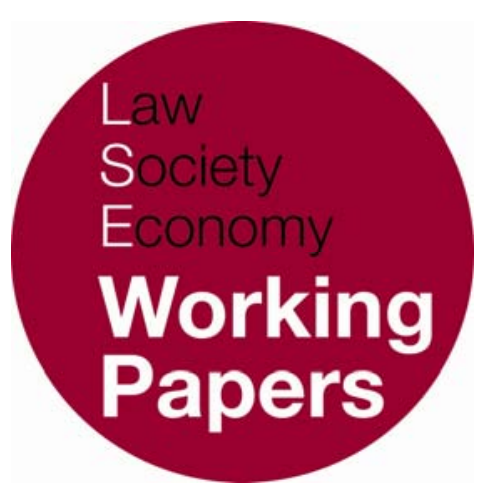

\title{
Is There A Human Right Not to Be a
}

\author{
Trade Union Member?
}

\section{Labour Rights under the European}

\section{Convention on Human Rights}

\author{
Virginia Mantouvalou
}

LSE Law, Society and Economy Working Papers 8/2007

London School of Economics and Political Science

Law Department

This paper can be downloaded without charge from LSE Law, Society and Economy

Working Papers at: www.lse.ac.uk/collections/law/wps/wps.htm and the Social Science Research Network electronic library at: http://ssrn.comabstract=1013493

(C) Virginia Mantouvalou. Users may download and/or print one copy to facilitate their private study or for non-commercial research. Users may not engage in further distribution of this material or use it for any profit-making activities or any other form of commercial gain. 


\title{
Is There A Human Right Not to Be a Trade Union Member? Labour Rights under the European Convention on Human Rights
}

\author{
Virginia Mantouvalou*
}

\begin{abstract}
This paper examines the protection of labour rights in the context of civil and political rights documents and explores the compatibility of closed shop arrangements with human rights law. It contributes to the relevant debates in two ways. First, it seeks to examine how the "integrated approach" to interpretation, a method increasingly preferred by the European Court of Human Rights when examining work-related complaints, affects the regulation of closed shops. Second, it attempts to resolve the apparent tension between individual rights and the collective interests of labour that is commonly articulated in both the case law and the academic literature. The paper suggests that, contrary to a widely held understanding, civil and labour rights share common values. Through the example of closed shops it is argued that the rights of workers and their unions can be enhanced rather than harmed by an effective and principled human rights regime.
\end{abstract}

\section{INTRODUCTION}

The protection of labour rights in human rights treaties has given rise to complex questions. An important labour right, included in both civil and political and socio-economic rights documents, is freedom of association, often specifically worded as a right to form and join trade unions. 'Freedom of organisation',

\footnotetext{
* Lecturer in Law, University of Leicester. This paper is based on a chapter of my $\mathrm{PhD}$ thesis, completed in 2007 at the London School of Economics. Earlier drafts were presented at the LSE Law Department $\mathrm{PhD}$ seminar, the Human Rights Centre PhD Affiliation Programme, and the workshop on the Legal Protection of Workers' Human Rights at the International Institute for the Sociology of Law in Onati, Spain. For valuable comments on an earlier draft I am grateful to the workshop organisers Colin Fenwick and Tonia Novitz, to the editors of the LSE Working Paper Series, to Hugh Collins, Conor Gearty, George Letsas, Margot Salomon and Bob Simpson. The paper is forthcoming in the book Legal Protection of Workers' Human Rights, Novitz, T. and Fenwick, C. (eds.).

${ }^{1}$ See article 11 of the ECHR, article 16 of the American Convention of Human Rights, article 22 of the International Covenant on Civil and Political Rights, article 10 of the African Charter of Human and Peoples' Rights.
} 
Kahn-Freund wrote, 'has two social and therefore two legal functions. It is a civil liberty, a human right, an aspect of freedom of association ... its existence and adequate guarantees for its exercise, are, however, also indispensable conditions for the operation of collective labour relations'. ${ }^{2}$ A major problem that often appears to obstruct its effective protection and which has given rise to concern about the impact of human rights law on labour law is the tension between these two aspects of the right. This tension can be otherwise described as one between the individual character of human rights and the protection of the collective interests of labour. Is this tension one that cannot be resolved?

The issue of closed shop agreements provides an excellent illustration of this tension. Closed shops are arrangements between one or more employers and one or more workers' organisations, according to which an individual can only be employed or retain her job upon condition of membership to a specific union. ${ }^{3}$ Voluntary association is desirable and it is protected in human rights treaties. Associations are usually formed by individuals who share some ideas or beliefs and who come together in order to promote these ideas and beliefs. People are free to choose whether they are going to join an association or not. Compelling an individual to relate with others, though, with whom she fundamentally disagrees in order to achieve some other purpose - however valuable that purpose may be appears unacceptable. People should be free from any such compulsion, and this is an important principle in modern liberal societies. Is compelled union membership as a condition of employment or to remain employed ever justified and compatible with human rights law?

In order to explore closed shops and their compatibility with human rights law, the present chapter looks at the European system for the protection of human rights. ${ }^{4}$ It contributes to the debates on the compatibility of closed shops with human rights law in two ways. First, having described a new interpretive method of the European Convention on Human Rights (ECHR) that the European Court of Human Rights (ECtHR or Court) increasingly follows when it examines work-related complaints, it assesses how it affects the regulation of closed shops. It suggests that this interpretive method - at least the way it has evolved to date - cannot provide an answer to the most difficult questions that the Court has to address. For this reason, the chapter takes a different route. It

2 Cited in Lord Wedderburn, 'Freedom of Association or Right to Organise? The Common Law and International Sources' in his Employment Rights in Britain and Europe (London: Lawrence and Wishart, 1991) 142.

${ }^{3}$ The first type of agreement is a pre-entry closed shop agreement, while the second is a post-entry closed shop. In the US the question is put in terms of a right to work against the trade union. On this see B. Hepple, 'A Right to Work?' (1981) 10 Industrial Law Journal 78. For a discussion of relevant US legislation see J.T. Delaney, 'Redefining the Right-to-Work Debate: Unions and the Dilemma of Free Choice' (1998) XIX Journal of Labor Research 425, and for a brief comparison between the US, the UK and Canada see K. Miller, 'Union Exclusivity Arrangements: A Comparative Overview' (2000) 16 International Journal of Comparative Labour Law and Industrial Relations $403 \mathrm{ff}$.

${ }^{4}$ For a presentation of the European system, see T. Novitz, 'Protection of Workers' Human Rights under Regional Human Rights Systems' forthcoming in the Legal Protection of Workers' Human Rights, Novitz, T., Fenwick, C. (eds.). 
attempts to resolve the tension between the individual character of human rights and the collective interests of labour, which is reflected in the regulation of closed shop arrangements, looking at the underlying values of the ECHR, which shed light on its object and purpose. It relies heavily on an insightful analysis by Stuart White on the compatibility of trade unionism with liberal values, ${ }^{5}$ and argues that there are indeed important challenges that the employment relation in general and closed shops in particular pose to human rights law. Concerns on the tension between the individual and the collective are not necessarily misplaced. Yet, they are overstated. Analysis of the underlying values of the ECHR reveals that in certain circumstances closed shops can be compatible with human rights law.

\section{THE ECHR AND LABOUR RIGHTS}

The ECtHR and the European Commission of Human Rights (EComHR or Commission) ${ }^{6}$ were traditionally reluctant to afford meaningful content to labour rights when looking at the impact of the ECHR on their protection. Influenced by Cold War prejudice and a belief that social and labour rights are by definition nonjusticiable, the Court and the Commission usually decided to afford them minimal protection. They found, for instance, that the right to associate does not necessarily encompass a right to consultation ${ }^{7}$ or a right to strike. ${ }^{8}$ In doing so, they allowed wide discretion to national governments and placed special weight on the fact that the rights under consideration were set down in the counterpart of the ECHR in the area of social and labour rights, the European Social Charter (ESC). When an alleged component of a Convention right was protected under the ESC, it was found to fall outside the material scope of the Convention. ${ }^{?}$

Human rights and labour law scholars were critical of this approach. Craig Scott, for instance, suggested that the ECtHR opted for what he called 'negative textual inferentialism' or a 'ceiling effect', which 'is created when an institution... refers to human rights commitments found in a legal instrument other than its own as a reason to limit the meaning, and thus the scope of protection, given to a right in that institution's own instrument'. ${ }^{10}$ Labour lawyers expressed concern that human rights and labour law are competitive areas by definition. The two bodies of rules serve incompatible goals and this is evident through the case law of

\footnotetext{
${ }^{5}$ S. White, 'Trade Unionism in a Liberal State' in A. Gutmann (ed.), Freedom of Association (Princeton, NJ: Princeton University Press, 1998) 330.

6 The EComHR was abolished in 1998 with the entry into force of Protocol 11 to the European Convention on Human Rights, ETS 155.

${ }^{7}$ National Union of Belgian Police v Belgium, App. No. 4464/70, judgment of 27 October 1975.

8 Schmidt and Dablstrom v Sweden, App. No. 5589/72, judgment of 6 February 1976.

${ }^{9}$ See, among others, $\mathrm{n} 7$ above [38].

${ }^{10} \mathrm{C}$. Scott, 'Reaching Beyond (Without Abandoning) the Category of "Economic, Social and Cultural Rights"” (1999) 21 Human Rights Quarterly 638-639.
} 
the Court, which denied trade unions any actual advantage of the Convention. ${ }^{11}$ It was suggested that in the examination of the possible components of the right to associate under article 11 of the ECHR, the Court did not treat the relevant provisions of the ESC 'as a more detailed map of the rights sketched out by the Convention'.12 The stance of the Court and the Commission led to characterisations of the case law as disappointing, ${ }^{13}$ 'individual and formalistic'. ${ }^{14}$ It was suggested that 'the Court has limited enthusiasm for the protection of trade union rights' and that it has shown 'a greater interest in the defence of individual autonomy than collective solidarity'. ${ }^{15}$

\section{AN INTEGRATED APPROACH TO INTERPRETATION}

Yet, a recent development inspired optimism to labour lawyers. A new method of interpretation emerged in post-2002 case law. Following the so-called integrated approach'16 to interpretation, the Court referred to social rights materials of the International Labour Organisation (ILO) and the European Committee of Social Rights (ECSR), monitoring body of the ESC, ${ }^{17}$ to widen the scope of the Convention's rights. A number of cases illustrate this interpretive method. In 2002, in Zehnalova and Zehnal, ${ }^{18}$ when the disabled applicants alleged that they had suffered a violation of certain ECHR rights, but also articles 12 and 13 of the ESC (right to social security and social and medical assistance), the Court, declaring the ESC part of their complaint inadmissible rationa materiae, stated: '.. it is not [the Court's] task to review governments' compliance with instruments other than the European Convention on Human Rights and its Protocols, even if, like other international treaties, the European Social Charter (which, like the Convention itself, was drawn up within the Council of Europe) may provide it with a source of inspiration'. ${ }^{19}$

Three important labour-related cases where the Court adopted an integrated approach to interpretation were Wilson and Palmer v. UK,20 Sidabras and Driautas v.

${ }^{11}$ K.D. Ewing, 'The Charter and Labour: The Limits of Constitutional Rights' in G.A. Anderson (ed.) Rights and Democracy, Comparative Essays in UK/Canadian Constitutionalism (London: Blackstone Press, 1999) 79-80.

${ }^{12}$ J. Hendy, 'The Human Rights Act, Article 11 and the Right to Strike' (1998) European Human Rights Law Review 588.

${ }^{13}$ K.D. Ewing, 'The Human Rights Act and Labour Law' (1998) 27 Industrial Law Journal 275. See also n 4 above.

${ }^{14}$ n 2 above, 144.

15 T. Novitz, International and European Protection of the Right to Strike (Oxford: OUP, 2003) 238

16 The term was used by Scheinin in 'Economic and Social Rights as Legal Rights' in Rosas et al. (eds.) Economic, Social and Cultural Rights (The Hague: Kluwer, 2nd ed, 2002) 32. For an overview see V. Mantouvalou, 'Work and Private Life: Sidabras and Driautas v. Lithuania' (2005) 30 European Law Review 573. See also I.E. Koch, 'The Justiciability of Indivisible Rights' (2003) 72 Nordic Journal of International Law 3.

${ }^{17}$ See $\mathrm{n} 4$ above.

18 Zehnalova and Zehnal v the Crech Republic, App. No. 38621/97, Admissibility decision of 14 May 2002.

${ }^{19}$ See also Mihailov v Bulgaria, App. No. 52367/99, Judgment of 21 July 2005, [33].

${ }^{20}$ Wilson, National Union of Journalists and Others v UK, App. Nos. 30668/96, 30671/96 and 30678/96, Judgment of 2 July 2002. 
Lithuania ${ }^{21}$ and Siliadin v. France. ${ }^{22}$ In Wilson, the ECtHR referred to ILO materials as relevant to the interpretation of article 11 of the Convention, which protects the right to form and join a trade union, and added that the Committee of Independent Experts (renamed to ECSR) and the ILO's Committee on Freedom of Association had criticised the UK legislation under scrutiny. Contrary to its past stance, the Court took cognisance of these materials in order to maximize rather than restrict the Convention's coverage. ${ }^{23}$ Following these developments, Collins argued that the Wilson case was the first decision to show 'how social rights can have indirect legal effect by influencing the interpretation of legally enforceable rights'. ${ }^{24}$

In Sidabras the Court examined the alleged violation of article 8 of the ECHR, which guarantees the right to private life, in conjunction with article 14 that prohibits discrimination. Following a similar approach to that adopted in Wilson, the ECtHR stated: '.. having regard in particular to the notions currently prevailing in democratic states, the Court considers that a far-reaching ban on taking up private-sector employment does affect "private life". It attaches particular weight in this respect to the text of Article $1 \rrbracket 2$ of the European Social Charter and the interpretation given by the European Committee of Social Rights... and to the texts adopted by the ILO'. ${ }^{25}$ Contrary to its usual practice before Wilson, it referred to the views expressed by monitoring bodies of the ILO and the ESC, in order to broaden the coverage of the Convention.

In Siliadin, finally, the ECtHR looked at the prohibition of slavery, servitude and forced or compulsory labour under article 4 of the ECHR. ${ }^{26}$ Reference to ILO instruments carried special weight in the determination of States' positive obligations. It also played a further important role in the examination of the material scope of article 4, which is one of the least invoked provisions of the otherwise widely explored ECHR. As there was neither much jurisprudence to build upon, nor much national practice to take into account, the Court decided to rely heavily upon relevant materials of the ILO and other Council of Europe and international instruments. ${ }^{27}$ It was with the aid of these instruments that it reached its decision that France was in breach of the Convention, adopting a modern reading of the prohibition of slavery.

\section{THE ECHR: A SYSTEM 'IN CONSTANT DIALOGUE'}

Interestingly, the adoption of the integrated approach in the examination of socioeconomic claims under the ECHR can be better understood if it is put in the

21 Sidabras and Driautas v Lithuania, App. Nos. 55480/00 and 59330/00, Judgment of 27 July 2004.

22 Siliadin v France, App. No. 73316/01, Judgment of 26 July 2005.

${ }^{23}$ K.D. Ewing, 'The Implications of Wilson and Palmer' (2003) 32 Industrial Law Journal 16.

${ }^{24}$ H. Collins, Employment Law (Oxford: OUP, 2003) 235.

${ }^{25}$ n 21 above, [47].

26 See V. Mantouvalou, 'Servitude and Forced Labour in the 21 ${ }^{\text {st }}$ Century: The Human Rights of Domestic Workers' (2006) 35 Industrial Law Journal 395.

${ }^{27}$ n 22 above, [ 51], [85-86]. 
broader picture of materials that are not part of the Convention, but which are used in the exploration of its values and evolving material scope. The dialogue between the ECtHR and other bodies has become common in recent years, when the Court has repeatedly and increasingly taken note of non-Convention materials. Reference to such materials has served as a means to resolve controversial issues or to support reversal of past case law.

The Convention system, Judge Rozakis suggested in this context, is in constant dialogue with other legal systems', 28 namely the European legal order, the international legal order and other national legal orders. ${ }^{29}$ The ECtHR and its judges, he added, 'do not operate in the splendid isolation of an ivory tower built with materials originating solely from the ECHR's interpretative inventions or those of the States party to the Convention'. Other bodies' materials have gained weight in the case law and ' $[t]$ his is a good sign for the founders of a court of law protecting values which by their nature are inherently indivisible and global'. 30

Examples of this interaction include cases such as Goodwin v. UK ${ }^{31}$ and Mamatkulov v. Turkey. ${ }^{32}$ In Goodwin, the Court had to examine the right to private life and the right to marry invoked by a claimant who had changed sex. In this context and before departing from its previous case law, the ECtHR looked at the developments that had taken place in Europe and also noted the stance of the European Union Charter of Fundamental Rights and the European Court of Justice on the matter. Similarly in Mamatkulov the Court had to assess whether the respondent state had to comply with a request for interim measures adopted by the ECtHR, although the provision on interim measures is only found in the internal rules of the Court and not in the text of the Convention. The Court examined whether interim measures are generally binding in international law and took note of various international legal materials. It referred to decisions of the UN Human Rights Committee, the UN Committee against Torture, the International Court of Justice and the Inter-American Commission and Court.

The general trend to have recourse to non-Convention materials is not hard to explain. Looking at these documents enhances the legitimacy of the decisions on difficult and controversial aspects of the ECHR. This is because the Court sometimes finds support in materials adopted by democratically elected and accountable bodies. In addition, it addresses criticisms that courts lack expertise and are, therefore, not competent to adjudicate on technical matters. By finding additional support and establishing consensus, it avoids criticisms that its views are arbitrary. Finally, looking at materials of other international bodies has the additional positive effect that it promotes coherence in supranational adjudication.

\footnotetext{
28 C.L. Rozakis, 'The European Judge as Comparatist' (2005) 80 Tulane Law Review 268.

29 ibid, 269-270.

30 ibid, 278-279

31 Christine Goodwin v UK, App. No. 28957/95, Judgment of 11 July 2002.

32 Mamatkulov and Askearov v Turkey, App. Nos. 46827/99 and 46951/99, Judgment of 4 February 2005.

Both Goodwin and Mamatkulov are discussed by Rozakis. n 28 above, 265-267.
} 
On work-related rights in particular, expertise of social and labour rights' bodies, and consensus between them has seemed to enhance the legitimacy of the decisions. The fact that the Court paid attention to social and labour rights treaties and case law, it further appeared, has led to outcomes which are friendlier to labour rights. Finally it has enriched the content of the Convention, because the Court has approached the rights protected therein as having social elements, and recognised in this way more weight to the interests of labour. Turning to the issue of concern to this article, how have these developments in the interpretation of the Convention affected the regulation of closed shops?

\section{CLOSED SHOPS UNDER THE ECHR}

The integrated approach was generally welcomed with optimism by labour lawyers. It was regarded as a positive first step, with potential to give answers to the complex questions that labour law poses to human rights law. Wilson, for instance, was described by Ewing as a decision that would 'restore confidence in Article 11 of the Convention', 33 while Collins suggested that 'it is important to appreciate that recent years have revealed a profound reorientation in the ECHR's interpretation of Convention rights in the context of the workplace and employment relations'. ${ }^{34}$ The expressed optimism, though, about the potential of this interpretive method was not long lasting. The issue of closed shops showed that reality is more complex than one would expect and that the integrated approach, at least the way it has evolved to date, cannot address the most difficult problems. This section first briefly presents how the ECtHR has dealt with closed shops in the past and then turns to a recent decision that addressed the matter.

\section{PAST CASE LAW}

The first decision that dealt with closed shops was Young, James and Webster v. UK. ${ }^{35}$ The applicants were dismissed because they refused to join the trade unions with which their employer, British Rail, signed a closed shop agreement when they were already employed. They alleged, among other things, that article 11 of the ECHR was violated, arguing that the negative aspect of the right to associate is an inherent aspect of the provision. Article 11 provides as follows:

1. Everyone has the right to freedom of peaceful assembly and to freedom of association with others, including the right to form and to join trade unions for the protection of his interests.

${ }^{33}$ n 23 above, 5.

${ }^{34}$ H. Collins, 'The Protection of Civil Liberties in the Workplace' (2006) 69 Modern Law Review 627.

35 Young, James and Webster v UK, App. Nos. 7601/76, 7806/77, judgment of 13 August 1981. 
2. No restrictions shall be placed on the exercise of these rights other than such as are prescribed by law and are necessary in a democratic society in the interests of national security or public safety, for the prevention of disorder or crime, for the protection of health or morals or for the protection of the rights and freedoms of others. This article shall not prevent the imposition of lawful restrictions on the exercise of these rights by members of the armed forces, of the police or of the administration of the State.

The ECtHR said that setting no limitations to compelled association, would strike at the very substance of article 11 . It stated that 'a threat of dismissal involving loss of livelihood is a most serious form of compulsion', 36 which could give rise to issues under the Convention. The majority of the Grand Chamber found that the limitation imposed upon negative freedom of association was disproportionate and in breach of the ECHR.

Closed shops were later examined in Sibson v. UK ${ }^{37}$ and Sigurjonsson v. Iceland. ${ }^{38}$ The applicant in Sibson would have had to move to another depot should he decide to not join a particular trade union. The facts differed from Young, James and Webster in a number of respects. First, the fact that Sibson used to be a member of the specific union (TGWU) before it signed a closed shop agreement with his employer, but resigned from it following a personal dispute, and that he was willing to rejoin the union if he received a public apology showed that his opposition to rejoining the TGWU was not 'on account of any specific convictions'. ${ }^{39}$ Second, the closed shop agreement was not yet in force, when the applicant resigned. Third, and '[a]bove all', according to the Court, 'the applicants in the earlier case were faced with a threat of dismissal involving loss of livelihood ... whereas Mr Sibson was in a rather different position'. He had the option to move to a nearby depot, where he would have no obligation to join TGWU, and where his working conditions would not be much different than before. These factors made the majority of the ECtHR decide that there had been no violation of article 11 of the ECHR.

Sigurjonsson, finally, had to become a member of a specific association, Frami, in order to retain a taxi driver's licence, which would be revoked, if he left the association. The obligation to join a union here was imposed on the applicant by national legislation. The majority of the Court held that Iceland could promote Frami's aims in some other way, and that imposing a duty of membership contrary to the applicant's convictions was a disproportionate interference with article 11 of the Convention.

36 n 35 above, 55. Of particular importance, here, was the fact that British Rail was a nationalised industry.

37 Sibson v UK, App. No. 14327/88, Judgment of 20 April 1993.

38 Sigurdur Sigurjonsson v Iceland, App. No. 16130/90, Judgment of 30 June 1993.

39 n 37 above, 29. 


\section{SORENSEN AND RASMUSSENV DENMARK}

The 2006 judgment of the Grand Chamber in Sorensen and Rasmussen v. Denmark ${ }^{40}$ is of great importance for a number of reasons. Not only is it the most recent decision that examined the complex question of closed shop agreements, but it also illustrated the integrated approach as an interpretive method, opening at the same time new complex questions and avenues for research.

The first applicant, Mr Sorensen, was born in 1975. Before commencing his studies at university, he applied for the post of holiday-relief worker. The company had a closed shop agreement with a trade union called SID. Having been informed that he would not have full SID membership, because he was a holiday relief worker, the applicant told his employer that he no longer wanted to be a member of the union. He was immediately dismissed with no notice or compensation. The second applicant, Mr Rasmussen, was born in 1959. He was a gardener and a member of SID for some years, before he ceased his membership, because he disagreed with the union's political affiliations. He became a member of the Christian Trade Union. Having been unemployed for a few years, he then got a job at a nursery. Membership of SID was a condition of his new job. $\mathrm{Mr}$ Rasmussen, as a result, rejoined SID and took up his new post. Both applicants claimed before the ECtHR that Danish legislation, which permitted the existence of closed shop agreements, breached the negative aspect of the right to associate under article 11 of the ECHR. They further argued that they disagreed with the political views of SID and that they wished to join a different union.

The Court stated that article 11 of the ECHR encompasses a negative right to not associate next to its positive right to form and join an association. While compulsion to join a union does not always breach article 11, it went on to say, it may do so when it strikes at the very substance of the provision. The fact that this case involved a pre-entry closed shop agreement, while past case law had only examined post-entry agreements, did not alter the decision. There are important similarities between the two types of arrangements: 'Had [the applicants] refused they would not have been recruited. In this connection', it went on to say, 'the Court can accept that individuals applying for employment often find themselves in a vulnerable situation and are only too eager to comply with the terms of employment offered'. ${ }^{41}$ The Court accepted the Government's argument that the applicants could seek employment with an employer that was not covered by a union shop arrangement. It stated, though, that it would still have to look at the impact of the arrangement on each individual applicant. Looking at Mr Sorensen first, the Court said that the fact that he was dismissed without notice, in spite of his young age and of the fact that he would only take up the job 10 weeks before going to university, constituted such a restriction on his freedom of choice that it gave rise to issues under article 11. Mr Rasmussen, on

40 Sorensen and Rasmussen v Denmark, App. Nos. 52562/99 and 52620/99, Judgment of 11 January 2006.

41 ibid [59]. 
the other hand, had been unemployed for some time before taking up his job at the nursery. Should he resign SID membership, he would be dismissed with no right to reinstatement or compensation. Additionally, the sector of horticulture was covered by closed shop agreements to a significant extent.

In the instant case, both applicants objected to union membership for political reasons. To this, the Danish Government responded that they had an option of 'non-political membership' of SID. Turning to the examination of this option, the ECtHR stated that it was in reality non-existent. This was so for two reasons: first, the membership fee would not be reduced, and, second, the union might support political parties indirectly, through funds raised from other activities. The duty to become a member of a specific union was therefore considered to strike at the very substance of article 11 in the circumstances of the case.

Did the Government strike the right balance between the individuals' interests and the need of trade unions to operate effectively? To answer this question the Court first considered recent developments in Denmark and other Council of Europe States, which pointed towards a tendency to limit closed shop agreements, as they are seen as less indispensable for the effective protection of workers' rights. Despite the objections of trade unions, and having suggested that there is increasing consensus that such arrangements are not necessary for the protection of workers' rights, ${ }^{42}$ the Court then turned to the relevant case law of the European Committee of Social Rights to adopt an integrated approach to the interpretation of the ECHR. It referred to Conclusions of the ECSR, where it had repeatedly been found that the Danish legislation on closed shops was contrary to article 5 of the ESC on the right to organise. ${ }^{43}$ It also mentioned the 1989 EC Charter of the Fundamental Rights of Workers, which guarantees a right to join or not to join a trade union, and then made reference to the 2000 EU Charter of Fundamental Rights, which protects freedom of association and further states that nothing in it can be interpreted as restricting rights that are already protected in existing treaties and agreements. All these materials, it stated, showed that there is increasing consensus that closed shops are not necessary. Article 11 of the ECHR, the majority concluded by twelve votes to five, had been breached in respect of both applicants.

Five judges dissented from the majority's decision. Their opinions demonstrate the tensions and the complexity of the issue. Of special interest is the partly dissenting opinion of Judges Rozakis, Bratza and Vajic, who drew a distinction between the two applicants, based on the degree of compulsion that each of them faced. If Mr Rasmussen resigned from SID, he would be dismissed without compensation and with no real prospect of finding a job as a gardener, an area covered to a large extent by closed shop agreements. 'The threat of dismissal and the potential loss of livelihood which would result,' the dissenting Judges went

42 ibid [70-71].

43 ibid [72]. 
on to stress, 'amounted in our view to a serious form of compulsion which struck at the very substance of the right guaranteed by Article 11' ${ }^{44}$ For Mr Sorensen, on the other hand, it would be easy to find a similar job with an employer that was not covered by a closed shop. For this reason, the degree of compulsion that he faced did not amount to a violation of his right to associate.

Judge Zupancic put his emphasis on the problem of free riders, and Judge Lorenzen stressed the sensitive socio-political character of closed shops, which should lead to the recognition of a wide margin of appreciation. Moreover, the latter Judge argued, individuals, who look for a job, are compelled to accept terms that they disagree with and which may interfere with their personal life. In any case, he concluded, neither of the applicants was significantly affected by closed shops, as they both had the possibility to find employment with another employer.

\section{IN SEARCH OF A SOLUTION}

The decision in Sorensen and Rasmussen was disappointing to labour law scholars, for it left little scope for union security clauses that do not breach the ECHR. Following this latest judgment of the Grand Chamber, it is difficult to envisage a situation where a closed shop agreement will be found to be compatible with the Convention. Could there be any exceptions, though? In order to examine the compatibility of closed shop arrangements with the ECHR I will look at three possible solutions which the relevant case law suggests. I will first consider whether the way the integrated approach has evolved to date can provide a solution. I will then discuss whether the degree of compulsion that an employee faces when there is a closed shop agreement in place is the crucial factor to examine. Third, I will explore whether there is something in the character of the Convention that makes negative freedom of association always and by definition more weighty when it conflicts with the positive aspect of the right.

\section{THE INTEGRATED APPROACH}

Closed shops revealed the shortcomings of the integrated approach as it has evolved to date. In most past case law the ECtHR was unwilling to take into account ESC materials, for example, in its decision on whether the right to strike is an aspect of freedom of association. ${ }^{45}$ In refusing to do so, it stated that these issues are covered by the ESC and are for its own machinery to regulate. Contrary to this past negative textual inferentialism, the Court's stance on closed shops was different. From early on in its case law, in Sigurjonsson, the Court was not deferent to expert bodies. It was keen to refer to the case law of the Committee of

$44 \mathrm{i} b i d$, Dissenting Opinion, [5].

45 Schmidt and Dablstrom v Sweden, App. No. 5589/72, judgment of 6 February 1976. 
Independent Experts (current ECSR), which examined negative freedom of association and found that it is protected under article 5 ESC that protects the right to organise. ${ }^{46}$ In a similar fashion it made mention of the ILO's findings, according to which closed shops imposed by law are in breach of Conventions 87 on Freedom of Association and Protection of the Right to Organise and 98 on the Right to Organise and Collective Bargaining. In the same way, Judges Sorensen, Vilhjalmsson and Lagergren, dissenting in Young, James and Webster, pointed at the stance of the ILO and the ESC, ${ }^{47}$ which had expressed the view that union security arrangements should be regulated at national level. ${ }^{48}$ In other words, although in the examination of other labour-related matters the Court showed deference to other bodies, which were more competent to decide the labourrelated issues, when it looked at union security clauses, it relied on these bodies' findings from early on in its jurisprudence, in order to decide the case itself.

It is not only this inconsistency that is discomforting. There is a further important issue. In recent case law where the Court adopted an integrated approach to the interpretation of the Convention, the ILO and the ESC had taken a similar view on the matters under consideration. It is on this common stance, this consensus of the expert bodies, that the Court based its findings. With closed shops, though, things were different. This is because while both the ILO and the ECSR have had to deal with them, they adopted a different stance. The ILO has refrained from interference with the matter. ${ }^{49}$ In the context of article 2 of Convention 87, which provides that '[w]orkers and employers, without distinction whatsoever, shall have the right to establish and, subject only to the rules of the organisation concerned, to join organisations of their own choosing without previous authorisation', the ILO Committee on Freedom of Association has said that 'it leaves it to the practice and regulations of each State to decide whether it is appropriate to guarantee the right of workers not to join an occupational organisation, or on the other hand, to authorise and, where necessary to regulate the use of union security clauses in practice'.50 It is only union security clauses imposed by law that would result in union monopoly, which would be found contrary to Conventions Nos. 87 and 98.51

Things are different when it comes to the ESC. While to date most research has focused on the impact of materials of other expert bodies on the case law of the ECtHR, here things were more complicated and illustrate a particularly interesting aspect of the integrated approach - an integration which took place

\footnotetext{
46 n 38 above, [35].

47 The Committee's findings on the ESC changed later on.

48 A similar stance is to be found in Gustafsson v Sweden, App. No. 15573/89, Judgment of 25 April 1996, where Judges Martens and Matscher discuss both ESC and ILO provisions and jurisprudence.

49 n 40 above, [38].

${ }^{50}$ ILC, 43 ${ }^{\text {rd }}$ session, 1959, RCE, Report III, (Part IV), [36]. See also the 1994 General Survey on Freedom of Association and Collective Bargaining: Right of Workers and Employers to Establish and Join Organisations, [100].

51 See 259th Report, Case No. 1385, [551]. See also Committee on Freedom of Association, Digest of Decisions, 1996, [321].
} 
initially in the opposite direction. ${ }^{52}$ Article 5 ESC, which guarantees the right to organise, says that ' $[\mathrm{w}] \mathrm{ith}$ a view to ensuring or promoting the freedom of workers and employers to form local, national or international organisations for the protection of their economic and social interests and to join those organisations, the Contracting Parties undertake that national law shall not be such as to impair, nor shall it be so applied as to impair, this freedom'. In the past, the Committee had stated that it would not rule on the compatibility of union security clauses with the ESC. ${ }^{33}$ Following Young, James and Webster, though, the Committee reassessed its stance, ${ }^{54}$ and found that only state-imposed closed shops were contrary to the ESC. It also took a step further to hold that the State has a duty under the ESC to protect individuals positively from such arrangements. ${ }^{55}$ In this context, it has therefore been argued, 'the ECSR has become a more staunch opponent of the closed shop than the European Court of Human Rights ever dared to be, but it seems that the origin of its enthusiasm lies with the sentiments of the Court rather than its own initiative'. ${ }^{56}$

While the ILO, to conclude, has repeatedly held that closed shop arrangements are for national authorities to regulate, the ECSR has taken a more robust view on the matter, stating that these arrangements violate the right to associate under the ESC. Which of the two expert bodies should the ECtHR follow adopting an integrated approach to interpretation? Should it opt for the ILO's deferential approach or should it follow the ESC's more intrusive case law? This is a question that the integrated approach, the way it has evolved to date, leaves unanswered.

\section{DEGREE OF COMPULSION}

In Sorensen and Rasmussen, Judges Rozakis, Bratza and Vajic argued that the degree of compulsion that each individual employee faces should carry most weight in determining the compatibility of closed shops with article 11 of the Convention. Does the employee have the option to work for another employer, before she alleges that her human rights have been violated? Or is she really deprived of almost all alternatives? Individuals are not free if they are presented with the choice of either accepting a job and union membership or to have no job. ${ }^{57}$

To put it in the Court's words from Young, James and Webster, '[a]n individual does not enjoy the right to freedom of association if in reality the freedom of

${ }^{52}$ For an overview of the evolution of the Committee's stance towards closed shops, see The Right to Organise and Bargain Collectively (Social Charter Monographs - No. 5, Council of Europe Publishing, $2^{\text {nd }}$ ed, 2001) 23-29. See also L. Samuel, Fundamental Social Rights - Case Law of the European Social Charter (Strasburg: Council of Europe Publishing, 2002) 112-118.

${ }^{53}$ ECSR Conclusions I, 31.

${ }^{54}$ ECSR Conclusions VII, 32-33.

55 See, for instance, ECSR Conclusions IX-1, 47. Danish legislation has been repeatedly found in breach of this obligation. See, for instance, ECSR Conclusions XI-1, 77, ECSR Conclusions XII-1, 110, ECSR Conclusions XIII-1, 130.

56 n 15 above, 242.

57 This was Iceland's argument in $\mathrm{n} 38$ above, [33]. 
action or choice which remains available to him is either non-existent or so reduced as to be of no practical value. ${ }^{58}$ It is understandable that the burden placed upon the applicants in Young, James and Webster, who would be dismissed if they did not join the trade union, with which their employer signed an agreement while they were already employed, is real compulsion and may strike at the very substance of their right to associate. Turning to Sorensen and Rasmussen it is also not difficult to agree with the idea that for the latter of the applicants, the fact that he was already unemployed and had only a few alternative options, constituted real and strong compulsion. How about Sorensen though? Did his situation amount to a violation of his human rights under the ECHR? Or was the range of his choices real, making it hard to see why his Convention rights had been violated?

While Judges Rozakis, Bratza and Vajic's opinion appears attractive at first glance, it is difficult to see how a Court can measure the actual compulsion that each individual faces when she seeks employment or when she is dismissed. There is a significant danger of arbitrariness in the assessment of whether one really needs a specific job or not. Even a temporary job, for instance, that a student takes up during her summer vacation may be extremely important to her. The income may contribute significantly to the continuation of her studies and the working experience may be crucial for her future work prospects. It is hard to see how one can draw clear principles based on this element of compulsion, which on the view of the dissenting Judges should carry central weight. The degree of compulsion cannot therefore lead to clear principles for the regulation of closed shop agreements under the ECHR.

\section{THE CONVENTION'S OBJECT AND PURPOSE: A LIBERTARIAN BILL OF RIGHTS?}

Judge Martens joined by Judge Matscher, dissenting in Gustafsson, claimed that when the negative and positive aspect of the right to associate are in conflict, the former should in principle prevail. This is due to the character of the ECHR. 'The Convention', they argued, 'purports to lay down fundamental rights of the individual and to furnish the individual an effective protection against interferences with these rights'. ${ }^{59}$ The right to dissociate, being a right of the individual, should therefore carry more weight when it conflicts with the right to associate, which is, on this reading of the ECHR, a positive right. Is this statement correct? This is highly questionable. Its first mistake lies in that it suggests that positive freedom of association is not an individual right, unlike its negative aspect. This is a false assumption. The right to associate is an individual right, like all other human rights. Nonetheless, it can only be exercised collectively, in association with others. There is nothing in the nature of the right, therefore, that makes it less weighty than negative freedom of association, when its two aspects are in conflict.

58 n 35 above, [56].

${ }^{59}$ Gustafsson, n 48 above, Dissenting opinion of Judges Martens and Matscher, [8]. 
Second, and more generally, the above suggestion of the dissenting Judges implies that the ECHR is a libertarian bill of rights and that its interpretation should be guided by libertarian principles, which reflect its object and purpose. ${ }^{60}$ Libertarians oppose union security clauses because they are considered to limit employees' and employers' freedom of choice, and may also have an impact on economic efficiency. ${ }^{61}$ Is this suggestion correct?

The ECHR is not a libertarian bill of rights and there is nothing in its character, its object and purpose, to suggest that negative freedom of association is to be given priority over the positive aspect of the right. The Convention is an egalitarian document. First of all, the ECHR contains an anti-discrimination provision. Article 14 is not a free-standing equality clause, but only prohibits discrimination in the enjoyment of other ECHR rights. ${ }^{62}$ The construction of the clause is narrow, at first glance, and leaves little scope for the protection against unequal treatment in the enjoyment of all human rights. The evolving egalitarian character of the Convention, however, has led to decisions, where the Court looked at other substantive provisions of the ECHR in conjunction with article 14 and opted for a wide interpretation. It found that a complaint may 'fall within the ambit' of the relevant right, without holding that there has been a breach of the substantive provision alone. ${ }^{63}$ In this way, it gave article 14 a somewhat autonomous meaning of a free-standing equality clause.

Moreover, importantly for present purposes and increasingly over the last few years, the Court has often included social components in the material scope of the Convention when a substantive provision was read together with the antidiscrimination clause, which it would have otherwise been reluctant to protect. ${ }^{64}$ Through article 14, and in particular when it was read in conjunction with the right to property, the ECtHR often adopted an integrated approach to the interpretation in non-labour related matters and read socio-economic rights into the Convention. ${ }^{65}$ A particularly interesting example here is Koua Poirrez. v. France. ${ }^{66}$ The decision involved discrimination in the enjoyment of social benefits on the basis of nationality. The Court found that a non-contributory right could give rise to a pecuniary right which falls within the ambit of article 1 of the Convention's $1^{\text {st }}$

${ }^{60}$ Article 31 of the Vienna Convention on the Law of Treaties provides in its first paragraph: 'A treaty shall be interpreted in good faith in accordance with the ordinary meaning to be given to the terms of the treaty in their context and in the light of its object and purpose'.

61 On libertarian approaches to compelled association, see J. Cohen and J. Rogers, 'Associations and Democracy', in E.O. Wright (ed.) Associations and Democracy (London: Verso, 1995) 15 and for a liberal egalitarian response see 18-21.

62 Article 14 provides that ' $\mathrm{t}$ ] he enjoyment of the rights and freedoms set forth in this Convention shall be secured without discrimination on any ground such as sex, race, colour, language, religion, political or other opinion, national or social origin, association with a national minority, property, birth or other status.'

63 See, among others, Abdulazir, Cabales and Balkandali v the UK, App. Nos. 9214/80, 9473/81 and 9474/81, Judgment of 28 May 1985, [71] and Inze v Austria, App. No. 8695/79, Judgment of 28 October 1987, [36].

${ }^{64}$ Examples include the Sidabras case, n 21 above.

${ }^{65}$ See, for instance, Gaygusuz v Austria, App. No. 17371/90, Judgment of 16 September 1996.

${ }^{66}$ Koua-Poirrez, v France, App. No. 40892/98, Judgment of 30 September 2003. 
Additional Protocol on private property. In the examination of the complaint, it adopted an integrated approach to the interpretation of the ECHR, taking note of a relevant decision of the ECSR on the issue. ${ }^{67}$ The construction of the nondiscrimination provision, in other words, has led the Court to opt for a wide reading of other Convention rights, showing how the instrument has taken on an egalitarian meaning, which was not perhaps envisaged by its drafters.

A recent development, finally, which serves as further evidence that the Convention system has equality as its central value, is the entry into force of Additional Protocol 12, in April 2005. The Protocol sets down a free-standing equality clause. ${ }^{68}$ Its Explanatory Report stresses the central importance of equality and non-discrimination for international human rights law in general. The $12^{\text {th }}$ Protocol is unavoidably going to open the Convention's doors to more individual applications that will affect social rights, and this may explain why some Governments have not ratified it yet. ${ }^{69}$

The ECHR is not a libertarian document, contrary to what Judges Martens and Matscher suggested. Its object and purpose reflect egalitarian views. Is the notion of equality that the Convention promotes a narrow notion, though, or is it a rich ideal that encompasses ideals of social equality? The very existence of labour rights in articles 4 and 11 of the Convention suggests that there is no firm distinction between civil rights and socio-economic rights in the Convention, as the Court put it in Airey. ${ }^{70}$ At the same time, the case Kona Poirrez, which was presented above, shows that the understanding of the prohibition of discrimination in the enjoyment of other Convention rights is certainly not narrow.

The most important evidence of a richer notion of ECHR rights, which does not reflect libertarian values, but that embraces social elements, are, of course, decisions such as Sidabras, Wilson and Siliadin, where the Court adopted an integrated approach to interpretation. These decisions, in particular in juxtaposition to past cases that dealt with similar matters, demonstrate an increased interest in the protection of social components of Convention rights. 'The European Convention on Human Rights', it was observed in an analysis of the Council of Europe on social cohesion, 'the most famous normative instrument of the Council of Europe, does not contain social rights properly speaking, but concentrates on civil and political rights... On this basis the European Court of Human Rights has developed interpretations to all the rights contained in the

${ }^{67}$ ibid [29].

${ }^{68}$ Article 1 - General prohibition of discrimination:

'1. The enjoyment of any right set forth by law shall be secured without discrimination on any ground such as sex, race, colour, language, religion, political or other opinion, national or social origin, association with a national minority, property, birth or other status.

2. No one shall be discriminated against by any public authority on any ground such as those mentioned in paragraph 1.'

${ }^{69}$ On this see N. Grief, 'Non-Discrimination under the European Convention on Human Rights: A Critique of the United Kingdom Government's Refusal to Sign and Ratify Protocol 12' (2002) 27 European Law Review - Human Rights Survey 11-12.

70 Airey v Ireland, App. No. 6289/73, Judgment of 9 October 1979, [26]. 
convention, a jurisprudence that can be compared to the jurisprudence of national constitutional courts' the analysis continued and then recognised that '[t]he jurisprudence of the Court has also repercussions on the interpretation of the social rights, e.g. when certain social security benefits are understood as property'. ${ }^{71}$ In a similar fashion, the Court has protected the right to healthcare and the right to housing in decisions under article 8 of the Convention. ${ }^{72}$

In all these instances, the ECtHR examined complaints that the drafters of the Convention never envisaged, underlining at the same time its character as a living instrument with an object and purpose that is not static, but which evolves. These examples show that certain social elements have already been read in the Convention, reflecting a fuller understanding of the rights it protects and revealing its changing character, object and purpose. A document that was once adopted as a bulwark to totalitarianism has come to reflect egalitarian ideas and sometimes protect social and labour rights. The ECHR, to conclude, is not a document characterised by libertarian values, contrary to the view of Judges Martens and Matscher. It is a liberal egalitarian bill of rights that enshrines social concerns. This is evident both in the text and in recent case law of the Court, which makes these values visible and further develops them. Can these values shed light on the approach that the Court should adopt when it comes to closed shops?

\section{IS THERE A HUMAN RIGHT NOT TO BE A TRADE UNION MEMBER?}

The solution to the issue of closed shops under the Convention cannot be dictated by the integrated approach to interpretation, which has taken the form of mere reliance to experts' views. This is because expert bodies do not always agree on the regulation of social and labour matters. The degree of compulsion that each individual employee faces, additionally, does not provide adequate guidance to the Court, which may reach unfair decisions in its effort to measure how important a job is to an individual's well-being. It is only the character, the object and purpose of the Convention and its underlying values that can lead to clear principles in the case law. The Convention's egalitarian character with its increasing attention to social elements shows that closed shops are not always and by definition incompatible with article 11. Compelled association is in principle compatible with the ECHR, which recognises the importance of trade unionism and affords a role to labour rights as human rights. Workplace participation advances workers'

\footnotetext{
${ }^{71}$ See G. Battaini-Dragoni and S. Dominioni, 'The Council of Europe's Strategy for Social Cohesion', Conference on Social Cohesion, November 2003, available at http://www.hku.hk/socsc/cosc/Full\%20paper/ BATTAINI-DRAGONI\%20Gabriella\%2025.11.pdf, 11, footnote 9, emphasis added.

72 On the right to health see, among others, Lopez Ostra v Spain, App. No. 16798/90, Judgment of 9 December 1994. On the right to housing see Selcuk and Asker v Turkey, App. Nos. 23184/94 and 23185/94, Judgment of 24 April 1998. For a more detailed list of the relevant case law, see I.E. Koch, 'Dichotomies, Trichotomies or Waves of Duties?' 5 Human Rights Law Review 81 at footnote 39.
} 
claims against their employers. The possibility of playing a role in the decisions that influence their lives promotes their feelings of dignity and self-respect. Union shops should not therefore be completely banned, but could be protected by the Court.

Yet, there are two objections to the compatibility of closed shops with the ECHR that need to be dealt with at this point. First, one might suggest, trade unions are associations which promote a specific ideal of the good life and are, therefore, incompatible with a liberal bill of rights. Second, empowering a group of individuals - employees in this context - would be contrary to equality, which is also a central value of the Convention. Both of these objections can be rebutted.

\section{NEUTRALITY}

Stuart White, in an insightful essay on trade unionism in a liberal state, answered the question of whether an effective right to trade union membership is compatible with liberalism in the affirmative. Having drawn a useful distinction between expressive associations and instrumental associations, White showed that state protection and promotion of trade unionism can be compatible with liberal values, similar to the ones that the ECHR enshrines. He suggested that " $\mathrm{a}] \mathrm{n}$ expressive association is a community whose members are united by sharing a distinctive set of religious or ideological beliefs'..$^{73}$ There are, however, other associations, which are purely instrumental, and which the state may have a duty to promote. An instrumental association is 'an association whose primary purpose is to secure for its members improved access to strategic goods, such as income and wealth, the possession of which is important from the standpoint of more or less any conception of the good life. The goals of such an association', he went on to say, 'are independent of any particular conception of the good life or controversial ideology, and participation in such an association cannot be said, therefore, necessarily to express commitment to any particular conception of the good life or controversial ideology.... ${ }^{74}$ While in practice it will not always be easy to distinguish which association is of one or the other kind, in principle 'the primary purposes of a trade union, qua trade union, are essentially instrumental in kind: to increase members' access to certain all-purpose goods such as employment and income'.

Of course, trade unions will always be related to the political process. This, however, does not mean that they will support a specific view of a good life. Neutrality is here understood as ethical neutrality and not as political neutrality. '[A] trade union may often articulate its instrumental ambitions by reference to an overarching set of ideas about distributive justice and democratic citizenship', on White's view. 'Indeed, from a liberal standpoint, it is highly desirable that it should. But this does not necessarily make the union an expressive association, in the

${ }^{73} \mathrm{n} 5$ above, 334-335.

74 ibid. 
above sense, if the values to which it is appealing are, as they may well be, part of the shared public moral vocabulary of a liberal society. ${ }^{175} \mathrm{~A}$ trade union, then, may be neutral and compatible with liberalism, because it does not promote a specific ideal of the good life. This happens when it has as its primary function the promotion of workers' rights and their participation in decisions that affect their lives.

\section{EQUALITY}

Looking at the second possible objection, namely the belief that promoting unionism and employees' rights would be contrary to equality, White's analysis is again useful. White argued that it is not enough for a state to be neutral towards trade unions. A liberal state should adopt a 'power-adjusted conception of neutrality, ${ }^{76}$ which will balance the inequality of bargaining powers that characterises the employment relation. An approach that takes into account this power-adjusted conception of neutrality would be in line with the ECHR's character as an egalitarian document. This approach implies that the Court should not be reluctant to interfere with the regulation of labour matters. However, in doing so it should keep in mind the inequality of power that characterises the employment relation, on the one hand, and the importance of employee participation at the workplace, on the other.

\section{Closed SHops AND Human Rights}

Closed shops are compatible with neutrality and equality - both ideals that the ECHR reflects. While these values leave scope for union security clauses, it is important to recognise the potential conflict of compelled association with other rights. Closed shop arrangements may have an impact on individual liberties, such as negative freedom of association and freedom of expression, more generally. On the one hand, workers, both individually and in association with others, can act to promote their interests, and human rights law provides some minimum guarantees that their voice be heard through the protection of the right to form and join trade unions. At the same time, though, the effective protection of human rights should not permit trade unions to restrict other individual freedoms illegitimately.

The imposition of membership to an association with which one fundamentally disagrees infringes individual autonomy and state neutrality, and runs contrary to central values of the Convention. The general principle is that one should not be compelled to join an association if she disagrees fundamentally with its aims. This principle is instantiated in a case where the ECtHR examined compulsion to join a hunters' association. Discussing disagreement with the

75 ibid, 335.

76 ibid, 337. 
purposes of an association on ethical grounds, it held that compulsion to join such an association was in breach of article $11 .{ }^{77}$

Certain conditions have to be met, therefore, in order to avoid illiberal outcomes. Which are the more concrete principles that the Convention's underlying values suggest regarding the regulation of closed shops? Taking White's analysis as a starting point, and looking at the Court's decisions and dissenting opinions in the relevant case law, one can envisage such arrangements that do not breach the ECHR and that are compatible with its values.

Closed shop agreements are compatible with the Convention when either of the following two conditions is met. First, that a trade union is of a neutral, instrumental character, and does not support specific political parties; second, when a trade union does have political affiliations, that an option for non-political membership be offered. The first possibility would perhaps be rare in Europe, where trade unions are usually connected to left-wing politics. Yet, examples of unions that are non-political are not an unknown phenomenon globally. ${ }^{78}$ In the second and more common alternative, namely that of unions with political affiliations, an option of non-political membership would meet the requirements of the Convention. This option should not be merely theoretical, as was the case with Danish legislation in Sorensen and Rasmussen. It should be effectively guaranteed in practice. This would mean that - unlike the Danish case - the membership fee should be reduced for employees who do not support the union's political activities. Additionally, there should be a clear policy to ensure that fees paid by employees that have opted for non-political membership are spent to promote members' workplace interests, and not in support of a political party.

The idea that one should not be compelled to associate with others holding political views with which one disagrees was confirmed by the Court in another recent labour-related case, Associated Society of Locomotive Engineers and Firemen (ASLEF) v. UK. ${ }^{79}$ ASLEF involves negative freedom of association, but not from the viewpoint of the individual employee who is unwilling to associate, but from the viewpoint of the trade union that wishes to exclude an employee from membership. ${ }^{80}$ ASLEF, the applicant union, is a socialist labour association. $\mathrm{Mr}$ Lee, a train driver and member of a political party of the far-right, the British National Party (BNP), was a member of ASLEF. He was expelled from the union when its officers were informed of his membership of the BNP and some of his activities, such as handing out anti-Islamic leaflets and engaging in serious harassment of anti-Nazi demonstrators. In its letter to Mr Lee the union stated

${ }_{77}$ Chassagnou v France, App. Nos. 25088/94, 28331/95 and 28443/95, Judgment of 29 April 1999, [117]. See also, $\mathrm{n} 40$ above, [63].

78 A country where there are non-political - instrumental - trade unions is India.

79 ASLEF v UK, App. No. 11002/05, Judgment of 27 February 2007. For an analysis of the case before the decision of the ECtHR, see J. Hendy, K.D. Ewing 'Trade Unions, Human Rights and the BNP' (2005) 34 Industrial Law Journal 197. See also A.C.L. Davies, 'Workers' Human Rights in English Law', forthcoming in $\mathrm{n} 4$ above.

80 This can otherwise be seen as a right of individual members of a union with political affiliations not to associate with individuals who hold political views diametrically contrary to their own. 
that his membership of the BNP was contrary to its aims, and potentially harmful to its reputation. Mr Lee brought proceedings before UK Employment Tribunals on the basis of section 174 of the Trade Union and Labour Relations (Consolidation) Act 1992, which bans expulsion from a union on the grounds of membership to a political party. UK tribunals found in favour of $\mathrm{Mr}$ Lee and imposed on ASLEF an obligation to readmit him as a member.

Before the ECtHR, ASLEF complained that it had not been allowed to exclude from membership an individual who holds views that clash with its own, a situation that was in breach of article 11 of the Convention. The Court stated that a union should have a right to choose with whom it will associate in a way similar to individual employees. This is because ' $[\mathrm{w}]$ here associations are formed by people, who, espousing particular values or ideals, intend to pursue common goals, it would run counter to the very effectiveness of the freedom at stake if they had no control over their membership'. ${ }^{81}$

Yet, it implied that in the case of trade unions the balancing test between the right to associate and freedom of expression may be more complex than when one is dealing with other types of associations. This is because of the special role that unions may be afforded in representing the interests of employees before the employer. In such circumstances, when we are dealing with an association that promotes what can be described as a public purpose, compulsion to associate may be justified, even if there is a clash of political views. ${ }^{82}$ Here, nonetheless, the Court found that UK Employment Tribunals did not strike the right balance between Mr Lee's right to belong to a political party and the right of ASLEF to disassociate with him. The union's right to choose its members was not afforded adequate weight. Mr Lee's exclusion from membership had not been abusive, and the Tribunals had erred in imposing upon the union an obligation to accept him as a member. ${ }^{83}$ Expulsion would not be detrimental to him, moreover, for there was no closed shop agreement in place, while the union represented all employees in the collective bargaining process, irrespective of membership.

The Court held that placing restrictions on the union's right to choose with whom it will associate, notwithstanding the fact that the individual had political views that conflicted with its own, constituted an illegitimate interference with the Convention. Trade unions are often affiliated to political parties, and imposition of a duty to associate with an individual who holds views contrary to their own, constitutes a breach of negative freedom of association.

To sum up, the ECHR a civil and political rights instrument, includes a right to form and join a trade union and can provide broad protection for the labour right to organise, one of the fundamental rights that the ILO and the ESC promote. Not only is the ECHR an instrument that can assist in the promotion of the collective interests of labour. It is also a document with which the imposition

${ }^{81} \mathrm{n} 79$ above, [39].

82 ibid, [40].

${ }^{83}$ For the conditions in which exclusion from union membership may be abusive, see ibid [43]. 
of a duty of union membership may be compatible, if its underlying objectives are properly understood and the obligation to associate is accordingly construed.

\section{CONCLUSION}

The example of closed shops shows that human and labour rights share important values. The collective interests of labour are not irreconcilable with human rights law. The protection of freedom of association and closed shop agreements shed light on two different aspects of the issue. On the one hand, workers, both individually and in association with others, can act to promote their interests and human rights law provides some minimum guarantees that their voice be heard through the protection of the right to form and join trade unions. At the same time, though, the effective protection of human rights does not allow trade unions to restrict other individual freedoms illegitimately. Human rights law can protect an individual employee from such illegitimate interference. The ECtHR has not explored thoroughly the conditions in which union security clauses can be compatible with the ECHR. The evolving object and purpose of the Convention, however, can shed light on the relationship between the individual and the collective and offer guidance as to the principles on which the Court should rely. The example of closed shops finally shows that the rights of workers and their unions can be enhanced rather than harmed by an effective and principled human rights regime. 